\title{
Genotoxic and Biochemical Biomarker Responses in Meretrix Casta Exposed to Environmentally Relevant Concentrations of Cadmium
}

\author{
Avelyno D'costa, Soorambail K. Shyama*, Praveen Kumar M. K. and Swizzle Furtado
}

*Department of Zoology, Goa University, Goa, India

Received: : January 24,2017; Accepted: March 27,2017; Published: April 16,2017

*Corresponding authors: S.K. Shyama, Department of Zoology, Goa University, Goa-403206, India, Tel.: +91- 0832-6519364 (O);E-mail: skshyama@ gmail.com

\begin{abstract}
Cadmium (Cd) enters estuarine water by surface runoffs from mines, phosphate fertilizers from agricultural fields and other anthropogenic sources which may pose a threat to the fauna inhabiting these waters. Bivalve molluscs which are a source of seafood may accumulate $\mathrm{Cd}$ leading to deteriorated health of the organisms and may also cause various health consequences in man. The present study was carried out to assess the toxicity of $\mathrm{Cd}$ in the estuarine backwater clam, Meretrix casta. In the experimental setup, the bivalves were exposed to three environmentally relevant concentrations of $\mathrm{CdCl}_{2}$ $(0.75 \mu \mathrm{g} / \mathrm{L}, 1.5 \mu \mathrm{g} / \mathrm{L}, 3 \mu \mathrm{g} / \mathrm{L})$ for a period of 15 days. Genotoxicity tests [Micronucleus Test (MN) and comet assay], oxidative stress parameters [Catalase Assay (CAT) and Lipid Peroxidation Assay (MDA)], neurotoxicity test [Acetylcholinesterase Assay (AChE)] and physical condition (condition index) were employed to evaluate the effects of Cd in M. casta. A dose-dependent increase of DNA damage was seen at all the concentrations of $\mathrm{Cd}$. Catalase activity was not significantly changed at the lowest concentration compared to the control, but increased significantly at the higher concentrations. Lipid peroxidation was found to be significantly increased at all the concentrations of $\mathrm{Cd}$. However, the levels of $\mathrm{AChE}$ were found to decrease in a dose-dependent manner. The condition index ratio was also found to be lowered with increasing dose. DNA damage was highly correlated with oxidative stress suggesting the mechanism of action of $\mathrm{Cd}$ on DNA. Oxidative stress was negatively correlated with AChE and may possibly be a contributing factor to neurotoxicity. M. casta can therefore be used as a potential sentinel species for monitoring the $\mathrm{Cd}$ in the estuarine environment using these biomarkers.
\end{abstract}

\section{Introduction}

Cadmium (Cd) occurs naturally in sedimentary rocks and soils in the environment and is also a constituent of zinc, lead and copper ores. It is used extensively in various applications such as anticorrosive agents, stabilizers in PVC products, in pigments, a neutron-absorber in nuclear power plants and the manufacture of nickel-cadmium batteries. It is also present in phosphate fertilizers (1). Cd can therefore be released into the aquatic environment from sources such as rainwater runoffs from metal mining sites, mine drainage water, phosphate fertilizers, sewage treatment plants landfills and hazardous waste sites $(2,3)$. Cd is known to be implicated in carcinogenesis either through oxidative stress or inhibition of DNA repair processes (4). The Environmental Protection Agency has thus classified Cd as a Group B1 carcinogen and is considered to be a probable human carcinogen (5). The toxicity of $\mathrm{Cd}$ is well documented in plants and is known to affect various important processes (6). In animal models such as fish, acute and sub-chronic exposure to $\mathrm{Cd}$ leads to alterations of gill epithelium, liver and kidneys and also affects enzymes such as acetyl cholinesterase $(7,8)$. In molluscs, $\mathrm{Cd}$ exposure results in reduction of growth rate and mortality due to impairment of several metabolic functions $(9,10)$. Several studies have also reported the genotoxicity of Cd in various animal models (11-15). The effect of Cd on DNA may be indirect, via the action of reactive oxygen species thus leading to oxidative DNA damage (16). Further, metal-induced genotoxicity is predominantly due to the inhibition of the DNA repair process (17).

Molluscs, particularly bivalves have been popularly used as "sentinels" to detect pollution caused by a wide array of contaminants in the environment (18). The advantage of using bivalves is due to their intimate association with the sediment, filter- or suspension-feeding habit and their ability to bioaccumulate various contaminants. Bivalves can selectively concentrate metal ions several hundred times from their surrounding water by several mechanisms such as the ingestion of particulate substances from suspended material, ingestion of food material that have acquired these metals, uptake by exchange onto mucous sheets of siphons and gills resulting in their incorporation into important physiological systems and formation of metal complexes with other organic molecules within the body (19). Cd, along with other hazardous metals is known to bioaccumulate in the tissues of bivalve molluscs which can pose a serious threat to the seafood consumers $(20,21)$. Cd also affects the early development of bivalves causing growth abnormalities and reduced survival (22). The International Agency for Research on Cancer has reported that regular consumers of bivalve molluscs are estimated to have weekly dietary cadmium exposures of $4.6 \mu \mathrm{g} / \mathrm{kg}$ of body weight (3).

In the present study, Meretrix casta (Chemnitz) commonly called the backwater or estuarine clam, was selected due to its occurrence in the backwaters or estuaries of both the east and west coast of India (23). It is consumed as local seafood in many parts along the coast of India and is available throughout the year. Despite its consumption, few studies are available on the toxicity of various contaminants that predominantly occur 
in these regions in $M$. casta. The presence of $\mathrm{Cd}$ in the waters along the coast of Goa may be attributed to the discharge of effluents from agrochemical industries (24). Oysters (Crassostea sp.) collected from a polluted estuary in Goa were found to have high concentrations of $\mathrm{Cd}$ in their soft tissues which are dependent on the speciation of $\mathrm{Cd}$ in the water and sediment $(25,26)$. High concentrations of Cd were also observed in oysters (C. madrasensis, C. gryphoides and Saccostrea cucullata) collected from three different polluted sites in Goa and were found to be consistently high in all the seasons (27).

\section{Materials and Methods}

\section{Quality Assurance and Quality Control}

The appropriate quality assurance methods of sample preparation, handling and preservation were carried out in accordance with US EPA procedures. All chemicals used were of analytical grade from Himedia (Himedia, India) unless specified otherwise.

\section{Maintenance of Meretrix casta}

Meretrix casta (Estuarine backwater clam) was selected for the present study as it is consumed by a majority of the coastal population and also due to its availability in the Goan estuaries throughout the year. The bivalves (both sexes) were collected from the intertidal zone with the help of skilled local fishermen from Palolem, a pristine location in Goa. This site is a clean, pristine beach with no known industrial activity or anthropogenic stress $(28,29)$. They were stored in a bucket with water from the study site and transported alive to the laboratory. They were then allowed to acclimatize in ordinary seawater from Palolem for 30 days. The water conditions were maintained as follows: temperature $25^{\circ} \mathrm{C}, \mathrm{pH} 7.5$, salinity $25 \mathrm{ppt}$, dissolved oxygen $7.5 \mathrm{mg} / \mathrm{L}$. The water was changed once daily to reduce fecal contamination.

\section{Treatment Schedule}

Bivalves were distributed in groups, each containing 10 individuals and were used for dose-response studies. Concentrations of $\mathrm{CdCl}_{2}$ were selected based on the 96h LC50 values in M. meretrix (30) and the environmental levels along the Goan coast (31). Accordingly, three sub-lethal concentrations of $\mathrm{CdCl}_{2}(0.75 \mu \mathrm{g} / \mathrm{L}, 1.5 \mu \mathrm{g} / \mathrm{L}$ and $3 \mu \mathrm{g} / \mathrm{L})$ were selected and were exposed to the bivalve groups for a period of 15 days. A group of bivalves was maintained in parallel without any $\mathrm{Cd}$ treatment and served as the negative control.

\section{Analysis of Samples}

The bivalves were dissected open, their gill and muscle tissues were cleaned thoroughly prior to the genotoxicity and biochemical analyses.

\section{Cell viability}

Prior to the comet assay and micronucleus test, the cell count and cell viability of the peripheral blood were checked to ensure that there were enough living cells to perform the assay employing trypan blue dye exclusion test. The samples showing more than $90 \%$ viability and a cell count of a minimum of $10^{6}$ cells $/ \mathrm{ml}$ were used for the tests.

\section{Micronucleus Test}

The Micronucleus (MN) test was performed following the protocol outlined by Baršiene et al. (32). A portion of the gill tissue was placed in a drop of methanol acetic acid mixture (3:1) on a clean glass slide. This tissue was then gently nipped with tweezers for a few minutes and the resulting cell suspension was then smeared and air-dried. The smears were fixed in methanol for $10 \mathrm{~min}$, stained with $5 \%$ Giemsa for 15 mins and allowed to dry. The frequency of Micronuclei (MNi) was recorded by scoring 2,000 intact cells per bivalve at 1000x magnification using an Olympus BX53 trinocular research microscope. Micronuclei (MNi) were identified according to the following criteria: (1) spherical or ovoid-shaped extra nuclear bodies in the cytoplasm (2) a diameter of $1 / 3-1 / 20$ of the main nucleus (3) non-refractory bodies (4) colour texture and optical features resembling those of the nucleus, and (5) the bodies completely separated from the main nucleus.

\section{Single Cell Gel Electrophoresis (Comet Assay)}

The comet assay was carried out as per Lee and Steinert (33). All steps were carried out in dim light to prevent photooxidation of DNA. Gill tissue $(0.1 \mathrm{~g})$ was homogenized gently with phosphate buffer saline ( $\mathrm{pH} 7.4)$ and the resulting cell suspension was passed through a muslin cloth to filter out tissue debris. This cell suspension was then embedded in Low Melting Agarose (LMA) on frosted microscopic slides. The cells were then lysed by placing the slides in a cold lysing solution $(2.5 \mathrm{M} \mathrm{NaCl}, 100 \mathrm{mM}$ $\mathrm{Na}_{2}$ EDTA, $10 \mathrm{mM}$ Tris, $10 \%$ DMSO and $1 \%$ Triton-X pH 10 ) at $4^{\circ} \mathrm{C}$, overnight. Following lysis the slides were placed in unwinding buffer (electrophoresis buffer, $\mathrm{pH} 10$ ) for 15-20 min to allow the DNA to unwind. Electrophoresis was then performed for $30 \mathrm{~min}$ at $300 \mathrm{~mA}, 25 \mathrm{~V}$ (Biorad electrophoresis unit). The slides were placed in neutralization buffer ( $400 \mathrm{mM}$ Tris base, $\mathrm{pH} 7.5$ ) for 5 min. The gel containing DNA was stained with ethidium bromide and examined using a fluorescence microscope (Olympus BX53) with a green filter at 200x magnification. Randomly selected nonoverlapping cells were screened and their comets were analyzed with the help of computer software, CASP (34) and the \% tail DNA was recorded. The \% tail DNA is the amount of DNA (in percent) present in the tail of the "comet" and is used as a measure of DNA damage (35).

\section{Catalase Assay}

Bivalves were dissected and their whole soft bodies were collected and homogenized in $50 \mathrm{mM}$ of Tris buffer $(\mathrm{pH}$ 7.4) containing $0.3 \mathrm{M}$ sucrose and $1 \mathrm{mM}$ EDTA. This suspension was then centrifuged at $10,000 \mathrm{xg}$ for $20 \mathrm{~min}$ at $4^{\circ} \mathrm{C}$ and the supernatant was collected. Catalase activity was carried as per Aebi (36) based on the decrease in absorbance of the test sample by the decomposition of $\mathrm{H}_{2} \mathrm{O}_{2}$. The reaction mixture consisted of $13.2 \mathrm{mM} \mathrm{H}_{2} \mathrm{O}_{2}$ in $50 \mathrm{mM}$ phosphate buffer ( $\mathrm{pH} 7.0$ ) and $0.1 \mathrm{ml}$ of the homogenate. The reduction in absorbance was measured at $240 \mathrm{~nm}$ using a multiwall plate reader (Analytical Technologies 
Ltd.) at $25^{\circ} \mathrm{C}$ over 3 minutes. Total protein concentration was measured by Bradford's method (37). The activity of Catalase (CAT) was expressed as $\mu \mathrm{mol} \mathrm{H}_{2} \mathrm{O}_{2}^{-1} \mathrm{~min}^{-1} \mathrm{mg}$ protein.

\section{Acetylcholinesterase Assay}

The Acetylcholinesterase (AChE) activity in whole soft bodies of bivalves was determined using the Ellman et al. (38) with modifications as described by Galloway et al. (39). Briefly, $50 \mu \mathrm{L}$ of sample homogenate was incubated in microtitre plates with $150 \mu \mathrm{l}$ DTNB $(270 \mu \mathrm{M}$ in $50 \mathrm{mM}$ sodium phosphate $\mathrm{pH}$ 7.4) at $25^{\circ} \mathrm{C}$ for $5 \mathrm{~min}$. The enzyme activity was initiated by the addition of $3 \mathrm{mM}$ acetylthiocholine iodide and the absorbance was measured at $412 \mathrm{~nm}$. The activity of AChE was expressed as nmol thiocholine ${ }^{-1} \mathrm{~min}^{-1} \mathrm{mgprotein}$.

\section{Malondialdehyde Assay}

The Malondialdehyde (MDA) assay which is used to test lipid peroxidation in the whole soft bodies of bivalves was carried out using a commercial kit (North West Life Science Specialities- NWK-MDA01). The assay is based on the reaction of MDA with Thiobarbituric Acid (TBA) forming a pink coloured MDA-TBA $_{2}$ adduct that absorbs strongly at $532 \mathrm{~nm}$. Butylated Hydroxytoluene (BHT) and EDTA are also added to the reaction mixture containing the sample homogenate to minimize oxidation of lipids. The activity of MDA was expressed as nmol MDA ${ }^{1} \mathrm{~min}^{-}$ ${ }^{1}$ mgprotein.

\section{Condition Index}

Bivalves were cleaned, dissected and the soft tissues were carefully separated from the hard shells. Both the soft tissue and the shells were placed separately in an oven (REMI) at $60^{\circ} \mathrm{C}$ overnight to determine their dry weights (40). Condition index (CI) was then calculated as follows:

$$
\text { Condition Index }=\frac{\text { Dry soft tissue weight }(\mathrm{g})}{\text { Dry shell weight }(\mathrm{g})} \text { X } 100
$$

\section{Statistical Analyses}

Statistical analyses of the data were carried out using IBM SPSS 23 statistical software package. The data were tested to meet the assumptions of normality and homogeneity prior to subsequent analyses by linear models. The data of the MN test and comet assay are expressed as percentage values and were therefore arc sine transformed whereas the data of CAT, AChE and MDA assays were log transformed. A one-way ANOVA was applied to test the effect of treatment on the \% MNi, \% Tail DNA, CAT, AChE, MDA and CI with a post hoc Dunnet's test to compare the different groups with the control within the same treatment group. Pearson's correlation with scatter plots were also used to test the relationship between the all the parameters. The data were considered to be statistically significant at $\mathrm{p}<0.05$.

\section{Results}

The dose response data of the MN test, comet assay, catalase assay, acetyl cholinesterase assay, malondialdehyde assay and condition index are presented in figure 1 (a-f). A significant dose dependent increase of DNA damage in the form of \% $\mathrm{MNi}$ was observed in the gill cells of $M$. casta at all the concentrations of $C d(p<0.05)$.
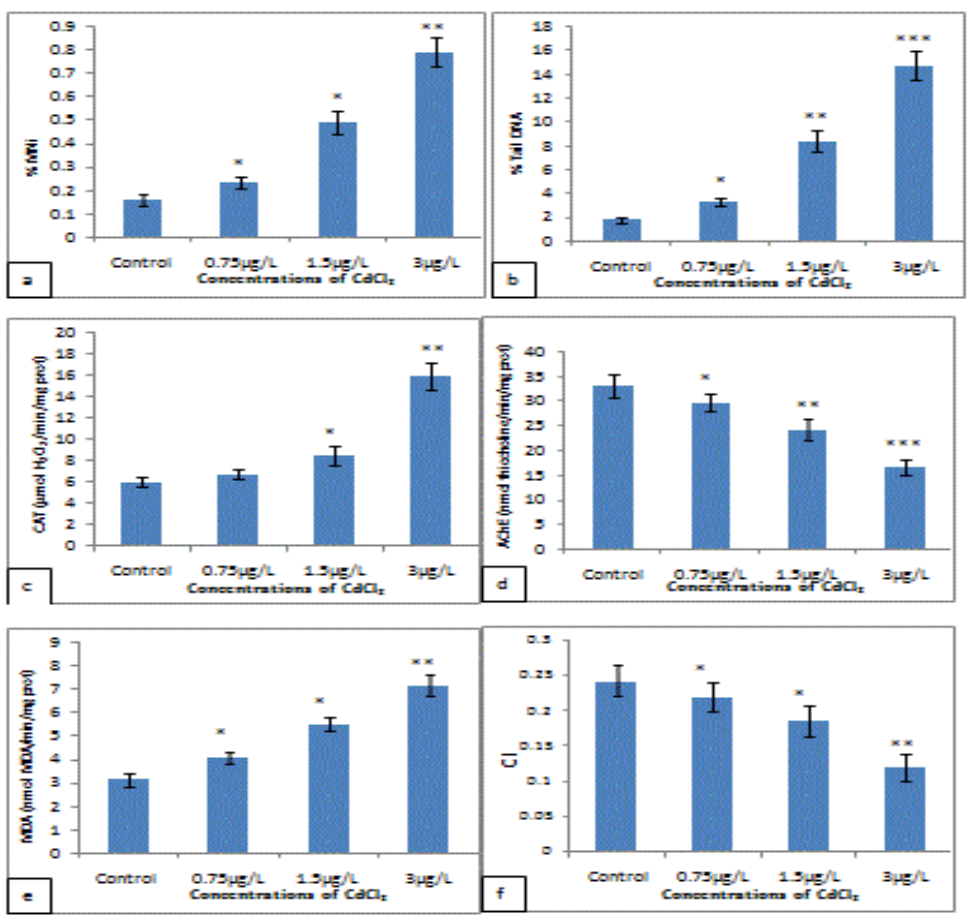

Figure 1: [Variations of biomarker responses (a-f) in M. casta exposed to different concentrations of CdCl2 (0.75, 1.5 and $3 \mu \mathrm{g} / \mathrm{L}$; Number of replicates $=3)$. \% MNi: Percentage Micronuclei, CAT: catalase, AChE: acetylcholinesterase, MDA: Malondialdehyde, CI: condition index. ${ }^{*} \mathrm{p}<0.05,{ }^{* *} \mathrm{p}<$ $0.01,{ }^{* * *} \mathrm{p}<0.001$ 
DNA damage in the form of \% tail DNA was also found to be significantly high at the $0.75 \mu \mathrm{g} / \mathrm{L}$ and $1.5 \mu \mathrm{g} / \mathrm{L}$ ofCd concentrations and was extremely significant at the $3 \mu \mathrm{g} / \mathrm{L}$ concentration $(\mathrm{p}<$ 0.001 ). The CAT activity did not change significantly at the 0.75 $\mu \mathrm{g} / \mathrm{L}$ concentration but increased significantly at the $1.5 \mu \mathrm{g} / \mathrm{L}(\mathrm{p}$ $<0.05)$ and the $3 \mu \mathrm{g} / \mathrm{L}(\mathrm{p}<0.05)$ of Cd. AChE activity was found to decrease in a dose-dependent manner whereas MDA activity showed an increasing trend with an increase in the concentration of $\mathrm{Cd}$ and was significant at all the doses $(\mathrm{p}<0.05)$. The CI ratio also decreased significantly with an increase in the concentration of Cd $(\mathrm{p}<0.05)$.

The effects of different concentrations of $\mathrm{Cd}$ on the variance of different tests are indicated in the one-way ANOVA (Table 1).

Table 1: one-way ANOVA of different concentrations of $\mathrm{Cd}$ on different biomarker responses in $M$. casta

\begin{tabular}{|c|c|c|}
\hline Dependent variable & \multicolumn{2}{|c|}{ Independent variable (Treatment) } \\
\hline & F value & $\mathrm{p}$ \\
\hline$\% \mathrm{MNi}$ & 926.86 & $<0.001^{* * *}$ \\
\hline \% Tail DNA & 1551.42 & $<0.001^{* * *}$ \\
\hline CAT & 535.95 & $<0.001^{* * *}$ \\
\hline AChE & 315.46 & $<0.001^{* * *}$ \\
\hline MDA & 515.75 & $<0.001^{* * *}$ \\
\hline CI & 124.21 & $<0.001^{* * *}$ \\
\hline
\end{tabular}

between DNA damage and the CI ratio. The scatterplots (Figure 2) further illustrate the associations between DNA damage and the other parameters.

A high positive correlation was observed between the \% MNiand the \% tail DNA ( $\mathrm{R}=0.95)$ as well as between both the genotoxicity parameters and the activities of CAT and MDA. However, a high negative correlation was observed between DNA damage and AChE levels $(R=-0.93,-0.94)$ as well as Different concentrations of Cd effects contributed the most to the \% Tail DNA ( $\mathrm{F}=1551.42, \mathrm{p}<0.001)$ followed by the $\% \mathrm{MNi}$ $(\mathrm{F}=926.86, \mathrm{p}<0.001)$. The activities of CAT, AChE and MDA and the condition index ratio were also significantly influenced by the different concentrations of $\mathrm{Cd}$.

The correlation matrix indicating the association between the different parameters is given in (Table 2).

\begin{tabular}{|c|c|c|c|c|c|}
\hline & $\% \mathrm{MNi}$ & $\begin{array}{c}\% \text { Tail } \\
\text { DNA }\end{array}$ & CAT & AChE & MDA \\
\hline$\% \mathrm{MNi}$ & - & & & & \\
\hline \%Tail DNA & 0.95 & - & & & \\
\hline CAT & 0.92 & 0.92 & - & & \\
\hline AChE & -0.93 & -0.94 & -0.92 & - & \\
\hline MDA & 0.95 & 0.96 & 0.89 & -0.92 & - \\
\hline $\mathrm{CI}$ & -0.86 & -0.90 & -0.87 & 0.87 & -0.85 \\
\hline
\end{tabular}
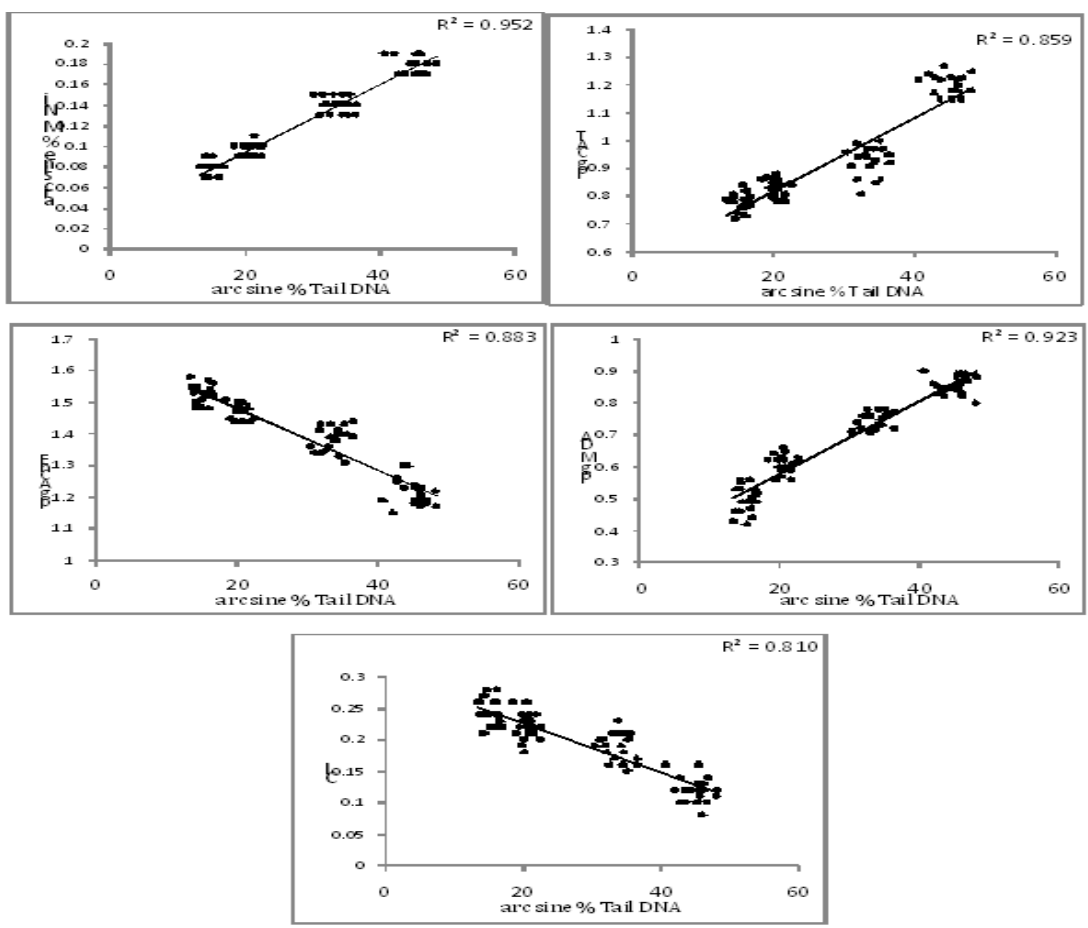

Figure 2: Scatter plots depicting the associations of DNA damage with other biomarker responses in $M$. casta exposed to different concentrations of $\mathrm{CdCl} 2(0.75,1.5$ and $3 \mu \mathrm{g} / \mathrm{L}$; Number of replicates = 3). \% MNi: Percentage Micronuclei, CAT: catalase, AChE: acetyl cholinesterase, MDA: Malondialdehyde, CI: condition index.

Citation: Avelyno D'costa, Shyama Soorambail K, Praveen Kumar M. K. and Swizzle Furtado (2017) Genotoxic and Biochemical Biomarker Responses in Meretrix Casta Exposed to Environmentally Relevant Concentrations of Cadmium. J of Biosens Biomark Diagn 


\section{Discussion}

The present study demonstrates the genotoxicity, neurotoxicity, oxidative stress and deteriorated condition induced by $\mathrm{Cd}$ in M. casta as indicated by the MN test, comet assay, AChE assay CAT assay, MDA assay and condition index. Cd was found to induce DNA damage in the gill cells of M. casta at all the concentrations studied. This is in agreement with the studies of Slobodskova et al. (41) where in they observed significant DNA damage induced by Cd in the gill cells of the clam, Corbicula japonica. Our observations were also on par with that of Sarkar et al. (31) in which they reported a significant increase of DNA damage with a concurrent decrease of DNA integrity in the gill cells of a marine gastropod, Nerita chamaeleon exposed to various concentrations of $\mathrm{CdCl}_{2}$. In another study, Cd was found to be clastogenic in the Pacific oyster (Crassostrea gigas), affecting the number of chromosomes in somatic cells significantly compared to control groups (42).

Significant increases in CAT activity were observed at the $1.5 \mu \mathrm{g} / \mathrm{L}$ and $3 \mu \mathrm{g} / \mathrm{L}$ concentrations. Similar observations were also reported by Macías-Mayorga et al. (43) in which Crassostrea angulata exposed to Cd showed an increase of CAT activity up to 7 days of exposure after which it was found to decrease significantly. Further, they attributed this oxidative stress in bivalves to the exposure to Cd. Liu et al. (44) proposed that $\mathrm{Cd}$ may generate free radicals by interfering with cellular antioxidant systems such as CAT.

Similarly, another consequence of oxidative stress was found to occur in M. casta as observed by the increase of a lipid peroxidation product, malondialdehyde (MDA). Dovzhenko et al. (45) also reported a similar increase of MDA in the bivalve Modiolus modiolus exposed to $\mathrm{Cd}$. The increase in MDA and other lipid peroxidation products lead to a decrease in the total oxygen radical scavenging activity. As a result, there is an accumulation of Reactive Oxygen Species (ROS) leading to oxidative stress in the organism. These ROS in turn affect DNA causing modification of DNA bases and DNA strand breaks $(46,47)$. Alternatively, Malondialdehyde (MDA) which is also highly mutagenic may form adducts with DNA and induce DNA damage (48). Our results are also supported by the observations of Xia et al. (30) in which an increase in the activities of both CAT and MDA in M. meretrix exposed to different concentrations of $\mathrm{Cd}$, which in turn induced the apoptosis of hepatopancreatic cells. Dailianis et al. (49) suggested that Cd may induce the formation of ROS and DNA damage by stimulating the production of Protein Kinase C (PKC) via adrenergic receptors. Therefore, based on the strong correlation between DNA damage and oxidative stress parameters, the DNA damage observed in M. casta in the present study may be attributed to oxidative stress as a result of $\mathrm{Cd}$ exposure.

We also observed a significant positive correlation between the frequencies of $\% \mathrm{MNi}$ and \% tail DNA ( $\mathrm{R}=0.95)$ which are represented in the form of scatter plots (Figure 2). The comet assay is able to detect repairable DNA damage such as DNA strand breakages, whereas the MN test detects more persistent DNA damage that are more difficult to repair $(50,51)$. These micronuclei are formed when a whole chromosome or a fragment of a chromosome does not get incorporated into either of the two daughter cells during cell division due to aneugenic agents that affect the spindle apparatus or clastogenic agents that damage and break the chromosome (52). Thus these two tests reflect different forms of environmental stress. The positive correlation in our study may be due to the conversion of the short term reversible damage to long term irreversible damage as a result of persistent $\mathrm{Cd}$ exposure.

Cd was also found to be neurotoxic in the bivalves as seen by the decreased concentration of AChE. The primary function of AChE is to catalyze the rapid hydrolysis of the neurotransmitter Acetylcholine (ACh) in the synaptic cleft thus terminating synaptic transmission. Cd may thus disrupt the function of AChE leading to an accumulation of ACh and overstimulation of cholinergic receptors. Our results are in agreement with that of Machreki-Ajmi and Hamza-Chaffai(53) in which cockles (Cerastoderma glaucum) transplanted from an unpolluted site to a site contaminated with $\mathrm{Cd}$ exhibited a significant inhibition of AChE activity. Our studies are also comparable with those of Dellali et al. (54) in which clams (Ruditapes decussatus) and mussels (Mytilus galloprovincialis) collected from sites polluted with heavy metals exhibited decreased acetylcholinesterase activity compared to those collected from unpolluted sites. Although the exact mechanism by which $\mathrm{Cd}$ causes inhibition of AChE in bivalves is not known, one possible mechanism may be due to ROS-mediated oxidative stress which is also seen to be negatively correlated in the present study (44).

A significant negative correlation was observed between the MN test and $\mathrm{CI}(\mathrm{R}=-0.86)$ as well as between the comet assay and $\mathrm{CI}(\mathrm{R}=0.9)$. A similar negative correlation between condition index and tissue levels of environmental contaminants of Littorina littorea, Mytilus edulis and Cerastoderma edule in a river system (Milford Haven Waterway) of Wales, UK was reported by Langston et al. (55). This decrease of condition of the organism may be attributed to altered DNA function and thereby resulting in an altered protein function which is ultimately required for normal physiological processes. The physiological state of the bivalve can also lead to changes in its feeding activity thereby altering its life cycle as a consequence (56). Another reason for the decrease in the $\mathrm{CI}$ ratio could possibly be the survival adaptive response of $M$. casta wherein they reduce the filtration rate or closure of the shell on exposure to contaminants (57).

\section{Conclusions}

The present study revealed that Cd $(0.75 \mu \mathrm{g} / \mathrm{L}, 1.5 \mu \mathrm{g} / \mathrm{L}$ and $3 \mu \mathrm{g} / \mathrm{L}$ ) induced DNA damage in $M$. casta which was caused as a result of oxidative stress. Increasing concentrations of $\mathrm{Cd}$ also inhibited the activity of AChE and lowered the condition index ratio. The comet assay and the micronucleus test along with the biomarkers of oxidative stress such as CAT and MDA, AChE assay and condition index can be reliably used to assess the genotoxicity of Cd in M. casta in the environment. Hence, the regular monitoring of estuaries for contaminants such as $\mathrm{Cd}$ is 
of utmost importance as the persistence of these contaminants could lead to significant decline in the natural populations of bivalves and may also pose a threat to the humans consuming them.

\section{References}

1. Godt J, Scheidig F, Grosse-Siestrup C, Esche V, Brandenburg P, Reich A et al. The toxicity of cadmium and resulting hazards for human health Journal of Occupational Medicine and Toxicology. 2006;1(1):22. doi $10.1186 / 1745-6673-1-22$

2. ATSDR. Draft Toxicological Profile for Cadmium. Atlanta, Georgia: US Department of Health and Human Services. 2008.

3. IARC. 2012. Arsenic, Metals, Fibres and Dusts. IARC monographs on the evaluation of carcinogenic risks to humans. 100:121-145

4. Waisberg M, Joseph P, Hale B, Beyersmann D. Molecular and cellular mechanisms of cadmium carcinogenesis. Toxicology. 2003;192(23):95-117.

5. Health effects Notebook for Hazardous Air Pollutants. Cadmium compounds. EPA. 2000

6. Benavides MP, Gallego SM, Tomaro ML. Cadmium toxicity in plants. Brazilian Journal of Plant Physiology. 2005;17:21-34. doi: 10.1590/ S1677-04202005000100003

7. Thophon S, Kruatrachue M, Upatham ES, Pokethitiyook P, Sahaphong S, Jaritkhuan S. Histopathological alterations of white seabass, Latescalcarifer, in acute and subchronic cadmium exposure. Environmental Pollution. Environ Pollut. 2003;121(3):307-320.

8. Jebali J, Banni M. Guerbej H, Almeida EA, Bannaoui A, Boussetta H. Effects of malathion and cadmium on acetylcholinesterase activity and metallothionein levels in the fish Serioladumerilli. Fish Physiology and Biochemistry. 2006;32:93. doi: 10.1007/s10695-006-0041-2

9. Ivanina AV, Sokolov EP, Sokolova IM. Effects of cadmium on anaerobic energy metabolism and mRNA expression during air exposure and recovery of an intertidal mollusk Crassostreavirginica. Aquat Toxicol 2010;99(3):330-342. doi: 10.1016/j.aquatox.2010.05.013

10. Nicosia A, Salamone M, Mazzola S, Cuttitta A. Transcriptional and Biochemical Effects of Cadmium and Manganese on the Defense System of Octopus vulgarisParalarvae. Biomed Res Int. 2015;2015:437328. doi: $10.1155 / 2015 / 437328$

11. Zharkov DO, Rosenquist TA. Inactivation of mammalian 8-oxoguanineDNA glycosylase by cadmium(II): implications for cadmium genotoxicity. DNA Repair. 2002;1(8):661-670.

12. Cavas T, Garankob NN, Arkhipchuk VV. Induction of micronuclei and binuclei in blood, gill and liver cells of fishes subchronically exposed to cadmium chloride and copper sulphate. Food and Chemical Toxicology. 2005;43(4):569-574. doi: 10.1016/j.fct.2004.12.014

13. Fourie F, Reinecke SA, Reinecke AJ. The determination of earthworm species sensitivity differences to cadmium genotoxicity using the comet assay. Ecotoxicol Environ Saf. 2007;67(3):361-368.

14. Çelik A, Büyükakilli B, Çimen B, Tașdelen B, Öztürk MI, Eke D. Assessment of Cadmium Genotoxicity in Peripheral Blood and Bone Marrow Tissues of Male Wistar Rats. Toxicology Mechanisms and Methods. 2009;19(2):135-140. doi: 10.1080/15376510802354979

15.Pavlaki MD, Araújo MJ, Cardoso DN, Silva AR, Cruz A, Mendo S, et al. Ecotoxicity and genotoxicity of cadmium in different marine trophic levels. Environ Pollut. 2016;215:203-212. doi: 10.1016/j. envpol.2016.05.010
16. Liu J, Qu W, Kadiiska MB. Role of oxidative stress in cadmium toxicity and carcinogenesis. Toxicol Appl Pharmacol. 2009;238(3):209-214. doi: 10.1016/j.taap.2009.01.029

17. Hartwig A, Schwerdtle T. Interactions by carcinogenic metal compounds with DNA repair processes: toxicological implications. Toxicol Lett. 2002;127(1-3):47-54.

18.Zuykov M, Pelletier E, Harper DA. Bivalve mollusks in metal pollution studies: From bioaccumulation to biomonitoring: Review. Chemosphere. 2013;93(2):201-208. doi: 10.1016/j. chemosphere.2013.05.001

19. The health hazards associated with the consumption of shellfish from polluted waters. EPA (Environmental Protection Agency). 1971.

20. Sokolova IM, Ringwood AH, Johnson C. Tissue-specific accumulation of cadmium in subcellular compartments of eastern oysters CrassostreavirginicaGmelin (Bivalvia: Ostreidae). Aquat Toxicol. 2005;74(3):218-228. doi: 10.1016/j.aquatox.2005.05.012

21. Marie V, Baudrimont M, Boudou A. Cadmium and zinc bioaccumulation and metallothionein response in two freshwater bivalves (Corbiculafluminea and Dreissenapolymorpha) transplanted along a polymetallic gradient. Chemosphere. 2006;65(4):609-617. doi: 10.1016/j.chemosphere.2006.01.074

22. Wang Q, Liu B, Yang H, Wang X, Lin Z. Toxicity of lead, cadmium and mercury on embryogenesis, survival, growth and metamorphosis of Meretrix meretrix larvae. Ecotoxicology. 2009;18(7):829-837. doi: 10.1007/s10646-009-0326-1

23. Seshappa G. Some observations on the backwater clam Meretrix casta (Chemnitz) in the Beypore and Korapuha estuaries. Indian J Fish. 1971;14:298-305

24. Sarkar A, Bhagat J, Sarker S. Evaluation of impairment of DNA in marine gastropod, Morulagranulata as a biomarker of marine pollution. Ecotoxicol Environ Saf. 2014;106:253-261. doi: 10.1016/j. ecoenv.2014.04.023.

25. Chakraborty P, Ramteke D, Chakraborty S, Chennuri K, Bardhan P. Relationship between the lability of sediment-bound $\mathrm{Cd}$ and its bioaccumulation in edible oyster. Mar Pollut Bull. 2015;100(1):344351. doi: 10.1016/j.marpolbul.2015.08.027

26. Chakraborty P, Ramteke D, Gadi SD, Bardhan P. Linkage between speciation of $\mathrm{Cd}$ in mangrove sediment and its bioaccumulation in total soft tissue of oyster from the west coast of India. Mar Pollut Bull. 2016;106(1-2):274-282. doi: 10.1016/j.marpolbul.2015.12.025

27. Shenai Tirodkar PS, Gauns MU, Ansari ZA. Concentrations of Heavy Metals in Commercially Important Oysters from Goa, Central-West Coast of India. Bull Environ Contam Toxicol. 2016;97(6):813-819. doi: 10.1007/s00128-016-1956-7

28. Sarkar A, Bhagat J, Sarker S. Evaluation of impairment of DNA in marine gastropod, Morulagranulata as a biomarker of marine pollution. Ecotoxicology and Environmental Safety. 2015;106:253-261.

29. Sarker S, Sarkar A. Role of marine pollutants in impairment of DNA integrity. J Clin Toxicol. 2015;5:244. doi:10.4172/2161-0495.1000244

30. Xia L, Chen S, Dahms HU, Ying X, Peng X. Cadmium induced oxidative damage and apoptosis in the hepatopancreas of Meretrix meretrix. Ecotoxicology. 2016;25(5):959-969. doi: 10.1007/s10646-016-1653-

31. Sarkar A, Bhagat J, Ingole BS, Rao DP, Markad VL. Genotoxicity of cadmium chloride in the marine gastropod Neritachamaeleon using comet assay and alkaline unwinding assay. Environ Toxicol. 


\section{5;30(2):177-187. doi: 10.1002/tox.21883}

32. Baršiene J, Andreikenaite L, Garnaga G, Rybakovas A. Genotoxic and cytotoxic effects in the bivalve mollusks Macomabalthica and Mytilusedulis from the Baltic Sea. Ekologija. 2008;54:44-50

33. Lee RF, Steinert S. Use of the single cell gel electrophoresis / comet assay for detecting DNA damage in aquatic (marine and freshwater) animals. Review. Mutat Res. 2003;544(1):43-64.

34. Konca K, Lankoff A, Banasik A, Lisowska H, Kuszewski T, Gózdz S, et al. A cross-platform public domain PC image-analysis program for the comet assay. Mutat Res. 2003;534(1-2):15-20.

35. Kumaravel TS, Jha AN. Reliable Comet Assay measurements for detecting DNA damage induced by ionising radiation and chemicals. Mutat Res. 2006;605(1-2):7-16.

36. Aebi H. Catalase in vitro.Methods Enzymol. 1984;105:121-126. doi: 10.12691/jfnr-2-7-5

37. Bradford MM. Rapid and sensitive method for the quantitation of microgram quantities of protein utilizing the principle of protein-dye binding. Anal Biochem. 1976;72:248-254.

38. Ellman GL, Courtney KD, Andres V, Featherstone RM. A new and rapid colorimetric determination of acetylcholinesterase activity. Biochem Pharmacol. 1961;7:88-95.

39. Galloway TS, Millward N, Browne MA, Depledge MH. Rapid assessment of organophosphorous/carbamate exposure in the bivalve mollusk Mytilusedulisusing combined esterase activities as biomarkers. Aquat Toxicol. 2002;61(3-4):169-180.

40. Filgueira R, Comeau LA, Landry T, Grant J, Guyondet T, Mallet A. Bivalve condition index as an indicator of aquaculture intensity: A metaanalysis. Ecological Indicators. 2013;25:215-229.

41. Slobodskova VV, Solodova EE, Slinko EN, Chelomin VP. Evaluation of the genotoxicity of cadmium in gill cells of the clam Corbicula japonica using the comet assay. Russian Journal of Marine Biology. 2010;36(4):311-315

42. Bouilly K, Gagnaire B, Bonnarda M, Thomas-Guyonb H, Renaulta T, Miramand P, et al. Effects of cadmium on aneuploidy and hemocyte parameters in the Pacific oyster, Crassostreagigas. Aquatic Toxicology. 2006;78(2):149-156

43. Macías-Mayorga D, Laiz I, Moreno-Garrido I, Blasco J. Is oxidative stress related to cadmium accumulation in the Mollusc Crassostre aangulata? Aquat Toxicol. 2015;161:231-241. doi: 10.1016/j. aquatox.2015.02.007

44. Liu J, Qu W, Kadiiska MB. Role of oxidative stress in cadmium toxicity and carcinogenesis. Toxicol Appl Pharmacol. 2009;238(3):209-214. doi: 10.1016/j.taap.2009.01.029

45. Dovzhenko NV, Kurilenko AV, Bel'cheva NN, Chelomin VP. CadmiumInduced Oxidative Stress in the Bivalve Mollusk Modiolusmodiolus. Russian Journal of Marine Biology. 2005;31(5):309-313.

46. Valavanidis A, Vlahogianni T, Dassenakis M, Scoullos M. Molecular biomarkers of oxidative stress in aquatic organisms in relation to toxic environmental pollutants. Ecotoxicology and Environmental Safety. Ecotoxicol Environ Saf. 2006;64(2):178-189. doi: 10.1016/j. ecoenv.2005.03.013

47. de Almeida EA, Bainy AC, de MeloLoureiro AP, Martinez GR, Miyamoto $\mathrm{S}$, Onuki J, et al. Oxidative stress in Pernaperna and other bivalves as indicators of environmental stress in the Brazilian marine environment: Antioxidants, lipid peroxidation and DNA damage. Comp Biochem Physiol A Mol Integr Physiol. 2007;146(4):588-600.
48. Łuczaj W, Skrzydlewska E. DNA damage caused by lipid peroxidation products. Cell Mol Biol Lett. 2003;8(2):391-413.

49. Dailianis S, Piperakis SM, Kaloyianni M. Cadmium effects on ROS production and DNA damage via adrenergic receptors stimulation: Role of Na+/H+ exchanger and PKC. Free Radic Res. 2005;39(10):10591070.

50. Hartmann A, Elhajouji A, Kiskinis E, Poetter F, Martus HJ, Fjällman A, et al. Use of the alkaline assay for industrial genotoxicity screening: comparative investigation with the micronucleus test. Food Chem Toxicol. 2001;39(8):843-858.

51. Klobucar GI, Pavlica M,Erben R, Papes D. Application of themicronucleus test and comet assay to mussel Dreissenapolymorphahaemocytes for genotoxicity monitoring of freshwater environments. Aquat Toxicol. 2003 ;64(1):15-23.

52. Udroiu I. The micronucleus test in piscine erythrocytes. Aquat Toxicol. 2006;79(2):201-204. doi: 10.1016/j.aquatox.2006.06.013

53. Machreki-Ajmi M, Hamza-Chaffai A. Assessment of sediment/ water contamination by in vivo transplantation of the cockles Cerastodermaglaucum from a non-contaminated to a contaminated area by cadmium. Ecotoxicology. 2008;17(8):802-810. doi: 10.1007/ s10646-008-0238-5

54. Dellali M, Barelli MG, Romeo M, Aissa P. The use of acetylcholinesterase activity in Ruditapesdecussatus and Mytilusgalloprovincialis in the biomonitoring of Bizerta lagoon. Comparative Biochemistry and Physiology Part C: Toxicology \& Pharmacology. 2001;130(2):227-235.

55. Langston WJ, O’Hara S, PopeND, Davey M, Shortridge E, Imamura M, et al. Bioaccumulation surveillance in Milford Haven Waterway. Environ Monit Assess. 2012;184(1):289-311. doi: 10.1007/s10661-0111968-z

56. Babarro JMF, Fernández-Reiriz MJ, Labarta U. Feeding behavior of seed mussel Mytilusgalloprovincialis: environmental parameters and seed origin. J Shellfish Res. 2000;19(1):195-201.

57. Akcha F, Burgeot T, Budzinski H, Pfohl-Leszkowicz A, Narbonne JF. Induction and elimination of bulky benzo[a]pyrene-related DNA adducts and 8-oxodGuo in mussels Mytilusgalloprovincialis exposed in vivo to B[a]P-contaminated feed. Mar Ecol Prog Ser. 2000;205:195206. 